\title{
Innovative Methods in Sustainable Urban Development and Water Management
}

\author{
Ágnes Agócsová, Zuzana Chodasová \\ Institute of Management, Slovak University of Technology in Bratislava, Vazovova 5, \\ 81243 Bratislava, Slovakia
}

\begin{abstract}
Innovative methods presently affect all sectors of the national economy contributing to the progress and overall development of the economy, and the living standard worldwide. Innovations are equally necessary both in the private and in public sectors therefore, the original innovative ideas in each sector are greatly accepted. Similar concept is significant for companies dealing with urban water management. New methods are available mainly for capturing and reusing of rainwater in urban areas which leads to a positive impact on sustainable urban water management regarding today's water scarcity problems. This article describes some of the most popular innovative methods and examples used for rainwater harvesting, recycling and reuse. As a result, the evaluation of the most suitable water harvesting techniques related to sustainable water management, and their application in the city of Brno in Czech Republic are described.
\end{abstract}

Keywords - Water management, Sustainable development, Innovative methods, Water harvesting

\section{Introduction}

The rapid increase of global human population during the 20th century had an impact on the use and consumption of all-natural resources on the Earth.

DOI: $10.18421 /$ TEM102-33

https://doi.org/10.18421/TEM102-33

Corresponding author: Ágnes Agócsová, Institute of Management, Slovak University of Technology in Bratislava, Slovakia.

Email: agnes.agocsova@stuba.sk

Received: 18 November 2020.

Revised: 20 March 2021.

Accepted: 29 March 2021.

Published: 27 May 2021.

(cc)Br-NC-ND(C) 2021 Ágnes Agócsová \& Zuzana Chodasová; published by UIKTEN. This work is licensed under the Creative Commons AttributionNonCommercial-NoDerivs 4.0 License.

The article is published with Open Access at www.temjournal.com
One of the most important sources for living organisms is water. The human being does not survive without water more than a few days. The increase in worldwide population has led to an increase in water demand and its use in environmental sphere, social and economic sectors which reflect in water scarcity problems occurring presently all around the world. Therefore, the sustainability of water management within the concept of a circular economy is an important topic in the present days. It is necessary to succeed in the principles of sustainable development because of the everyday increase in water scarcity.

The main aim of the paper is the analysis of different case studies with the focus on methods used by rainwater harvesting, its recycling and reuse in urban areas.

\section{Characteristic of Sustainable Development}

Sustainable development (SD) as a phrase has started to be used in the publications since the early 1980s. [1] Defined by WCED (1987), SD is a development that meets the needs of the present without compromising the ability of future generations to meet their own needs [2]. In the point of the increase in the worldwide water demand the water scarcity has started to seem like an issue regarding the future existence of living organisms in the Earth. As Beaulieu et al. (2016) has mentioned, the sustainability in development is a complex theory which efforts to merge together three development's dimensions: economic, environmental and social [1]. Through these different dimensions SD is connected with the term circular economy [3].

The idea of a circular economy (CE) has been figured by two British economists of environment Pearce and Turner in 1990. As they reminded in their book Economics of Natural Resources and the Environment, the open-ended economic system was developed without the inclination to recycling, which was reflected to the situation that the environment has been used as waste storage. Therefore, the openended system as not adequate one should be turned 
into a circular system while considering the connection between resources use and waste residuals [4]. Table 1 indicates the definition of the concept of CE defined by several authors.

\section{Table 1. Definitions of the Circular economy}

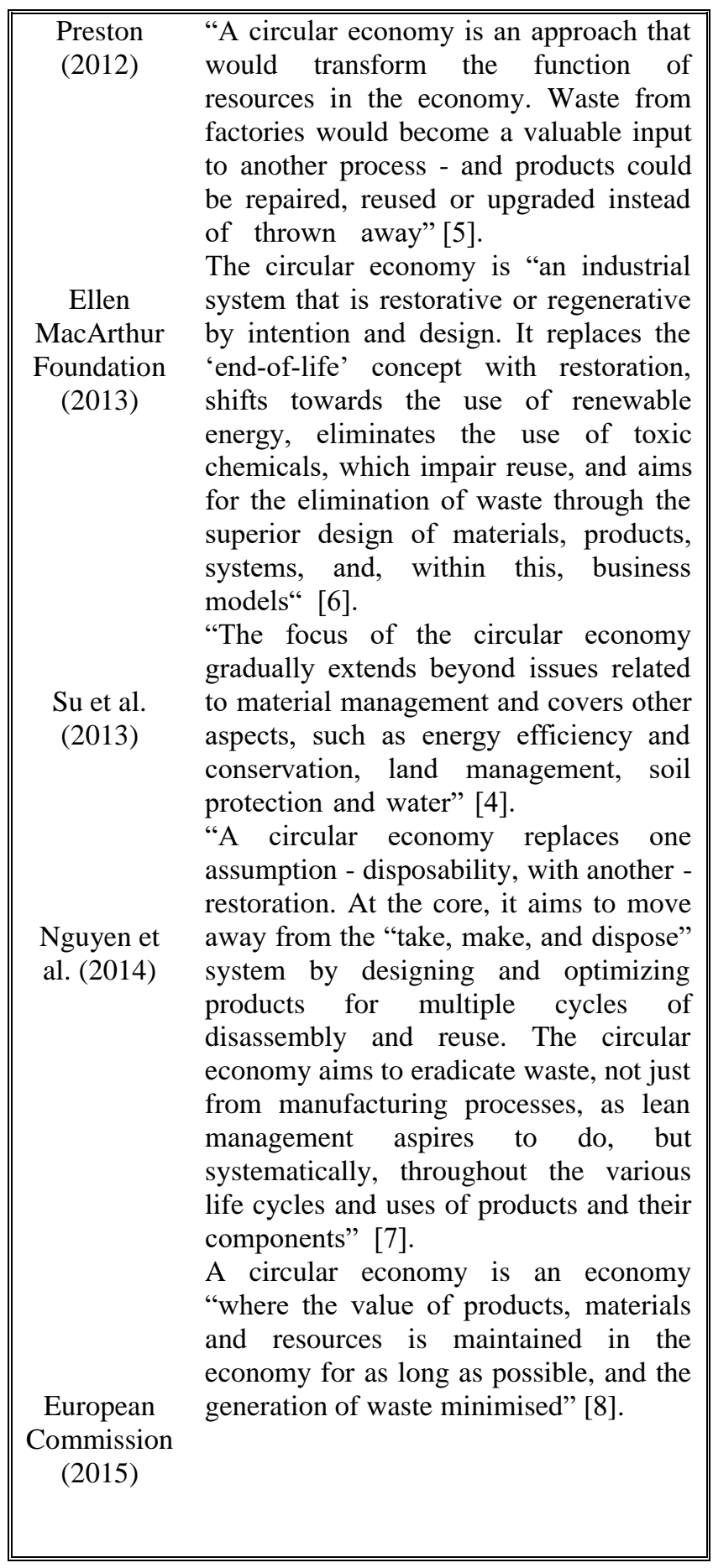

The disposability or single usage of the product has become an over-discussed issue of today's world. The single use of the products leads to the enormous use of natural sources and the creation of huge amount of waste. Therefore, it was necessary to start to consider the recycling and reusing of the products contributing to saving the natural sources needed for the production [9]. This process is supporting SD which is a basement of the system of CE. It helps to provide the growth of the economy while the use of the virgin resources, is decreasing. Nguyen et al. (2014) defined, that CE replaces the disposability by the restoration and reuse [7]. This idea is worth not only for material products but is also applicable in the utility of usage of natural resources.

$\mathrm{CE}$ as a closed-loop system is able to reuse the sources, energy and the material several times (even if for different purposes) with minimum processing required by each subsequent use.

Regarding water management and CE, several steps have been taken in action yet. The acceptance of the Circular Economy Package in 2015 by the European Commission was the important move which could lead to effective and sustainable water use. For the successful implementation, it is necessary to associate all the factors influencing water management, namely social, political, technological, economic, and environmental factors [10].

\section{Sustainable Water Management}

Water management sector is one of the largest idle opportunities for moving from waste to resources within a CE system. The practices of CE help companies reach sustainability targets and efficiency and save costs and fees. At the same time, the natural environment that business depends on is keeping preserved [11], [12]. It is important to start considering the real value of water as it is the most important resource. The wastewater and rainwater are important sources and assets that can be easily harvested and reuse. Recycling and reuse are central to a $\mathrm{CE}$ approach and lead to an improvement of worldwide water scarcity problems. A lot of states and corporations are starting to use the circular practices in production instead of linear models [13]. The proper policy and regulations are enabled to help economies to break away from a polluting economic trajectory and move to a 'clean' one. The movement to a CE brings more-efficient water use, combined with innovative methods. This transition leads to the economy's ability to handle problems of the growing imbalance between water supply and its demand [14].

Due to the effects of climate change on the environment, experts are increasingly concerned with sustainable water management. Sustainable management replaces linear methods associated with single use, leading to the enormous use of natural resources and the generation of large amounts of waste. This theory is applicable both in the economy sectors and in the water management sector (see 
Figure 1), where it is inclined to reuse several types of water (rain, gray, waste) after their additional treatment in the form of purification. A sufficiently dense network of green spaces with permeable surfaces can retain water from rainfall and thus slow down its surface runoff to nearby recipients.

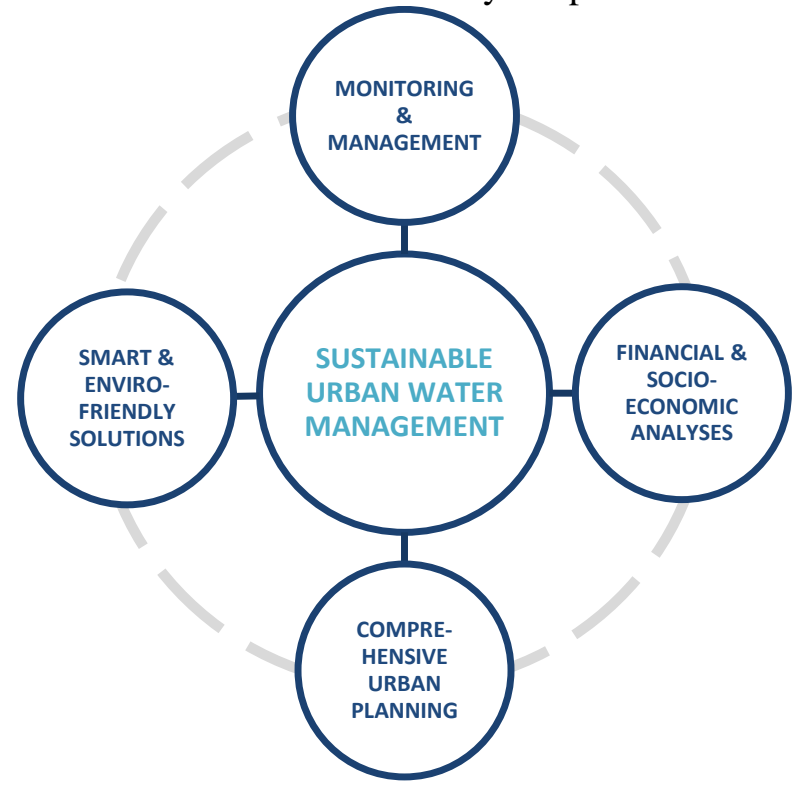

Figure 1. Approach to sustainable urban water management (source: Author, 2020)

The goal of sustainable rainwater management is to reduce rainwater runoff over the surface and allow it to infiltrate as close as possible to the source, ideally at the point of impact. In this case, rainwater management does not mean collecting and discharging it into the public sewer network, but reducing runoff using rainwater harvesting and reuse technologies, increasing rainwater infiltration into the soil surface and the possibility of subsequent natural evaporation. The aim of this concept is to "close the loop", thereby bringing rainwater back into the city's small water cycle, thereby contributing to the subsequent cooling of the city's microclimate.

Several techniques have been developed in recent years and the concept of sustainable rainwater management has been introduced in several countries around the world. The advantages of sustainable water management for local governments are the use of rainwater for irrigation, which will support the cooling function of the vegetation in the city and reduce its overheating on hot days, but also improve air quality. Another benefit for the municipality is the reduction of the intensity of some extreme weather events, especially due to the reduction of heat produced in the atmosphere above the city [15].

Proper integration of rainwater management also contributes to the visual and recreational facilities of urban areas. Another advantage is the prevention of damage to infrastructure, as the integration of measures includes the prevention of urban floods.
Like any innovative system, the application of rainwater management principles brings several challenges. The choice of suitable technologies for decentralized land drainage depends on a set of several factors. The most important are the infiltration capacity and permeability of the soil, the level of the groundwater level, the amount of surface runoff or the slope of the area. These and other factors need to be taken into account when adequately designing rainwater management systems in urbanizations.

\section{Green Infrastructure and its Role in Sustainable Urban Development}

Green infrastructure (GI) is the overall core concept of greenery in cities, which is most often associated with the concepts of sustainability, resilience and overall concept of smart cities. GI refers to a system of strategies and approaches that make the possibility to meet the requirements of urban adaptation to climate change while creating additional benefits for the community. It is an ecological approach to rainwater management using the ability to slow down, filter and absorb precipitation as close as possible to the point of impact on the earth's surface.

GI represents a shift in ideas from conventional urban drainage to an integrated, nature-friendly way that positively affects not only surface runoff, but also living conditions in cities and their long-term sustainability [16]. A fundamental change that such a nature-friendly method of drainage of the area brings is a wider range of possibilities where to bring rainwater. In contrast to the current situation, where water from precipitation is exclusively discharged into the sewerage network, GI methods offer several types of rainwater recipients with different priorities.

The concept of GI is one of the ways to cope with the problems of modern cities; it enables great innovation of solutions and cross-sectoral approaches. GI can help cities connect different urban resources to find effective and sustainable solutions [17]. Greenery in cities offers measures to mitigate and adapt to climate change and offers several benefits, including energy and carbon dioxide protection, air quality, urban hydrology, noise reduction, environmental benefits and social function.

The basic feature of GI is the aspect of interconnection and network. The purpose of GI is to create a natural network that creates a link between the places where people live and work. The basic principle of urban infrastructure planning is the development, maintenance and strengthening of ecological resources. Whether this process applies to public parks, the treatment of watercourses or the protection of grassland-rich places, in principle, is 
less important than the increase in resources alone. The main principles of GI are connectivity, multifunctionality and greening, as well as the promotion of green networks, adaptation to climate change, sustainable urban policy and strategic urban management practices.

Assessing the implementation of GI from a financial point of view may seem like a difficult process [18]. However, since this type of infrastructure provides multiple benefits for different areas, it is often cheaper, more sustainable, and more resilient than the choice of standard grey infrastructure. Therefore, when creating new projects and during revitalization, it is necessary to consider all the benefits associated with the implementation of GI first, make a comparison with currently used grey infrastructure, and base on the final analyses evaluate which type will be more suitable for the analysed area.

\section{Urban Rainwater Harvesting}

Increased concentration of the population in the urban areas has led to the increase of the volume of water-impervious surfaces such as pavements, roads, built-up areas and other infrastructure. The quality of drainage system of these surfaces is usually insufficient, with no emphasis on re-infiltration of water into the natural environment - soil profile and groundwater.

Dense urban development contributes to the current problem of so-called "flash floods" caused by heavy rain, which happen more frequently and more extremely during the summer period. These types of floods cause devastation of streets, buildings and public space and leave huge damage behind. One of the main causes of the weather extremes is the climate change caused by human and natural influences.

Cities are becoming every year hotter and they become heat island, therefore, the cooling of the urban microclimate is one of the current issues that need to be addressed. Since a large amount of precipitated water (almost all of it) is immediately drained to the sewerage system, the water does not have time and space to soak, for example, into the vegetation root system in the soil. The infiltration of the water and following evaporation helps to maintain constant temperature in the cities. The smaller the amount of water is evaporated from the area to the atmosphere, the more extreme the temperature differences occur. Therefore, it is necessary to start to retain the water from the precipitation directly in the area where it falls and to allow the evaporation into the air in the same area.

The main step for the collection of water in the city is its capturing. Capturing and eventual re-use of rainwater is possible in several ways by using different adaptation measures. There are several options for collecting and reusing of rainwater. The captured water can be re-used for irrigation of green areas in cities, filling the fountains or reservoirs. Water can be also re-used in households by the retention in the tanks for non-drinking uses (e.g. washing, toilet flushing, and space cooling). Another good solution of rainwater re-use is its direct infiltration into the soil profile up to the groundwater level in order to ensure the stability of groundwater.

\section{Methods and examples of the green infrastructure in Brno, Czech Republic}

Urban water management includes many of innovative methods which help to support the drainage of urban areas in a nature-friendly way in the context of the adaptation of the urban environment to climate change, which we face today. After including these measures to standard elements of urban planning, the cities will become more resilient, flexible and tempting not only for their citizens.

Application of adaptation measures inside the cities is a demanding process which requires a longterm sustainable planning approach including several aspects. Adaptation process of urban areas to negative effect of climate change has to be approached comprehensively for the whole urban environment.

Below is an overview of the application of innovative rainwater harvesting systems with the examples of their application in practice in the city of Brno in Czech Republic.

\section{Retention Tank in the Public Park}

Retention tanks are underground or above-ground tanks used to capture rainwater at the area where it falls, and capture water from the roofs of buildings or surrounding objects/infrastructure. They help in slowing down the discharge of rainwater into the sewer in areas with insufficient capacity of the sewerage system. Part of the water can be reused to irrigate green areas or as water element or natural biotope helping in cooling down urban microclimate, and part of the water is drained into the sewer by a controlled drain.

An example of a retention tank built in the part of the inhabited neighborhood in Brno city is described below. This water tank was built as a motivating example of urban rainwater management in the middle of the public park in Brno. The building process showed in Figure 2 had started in 2011 and was finished in 2013. This project was named "Under Sail Park". 

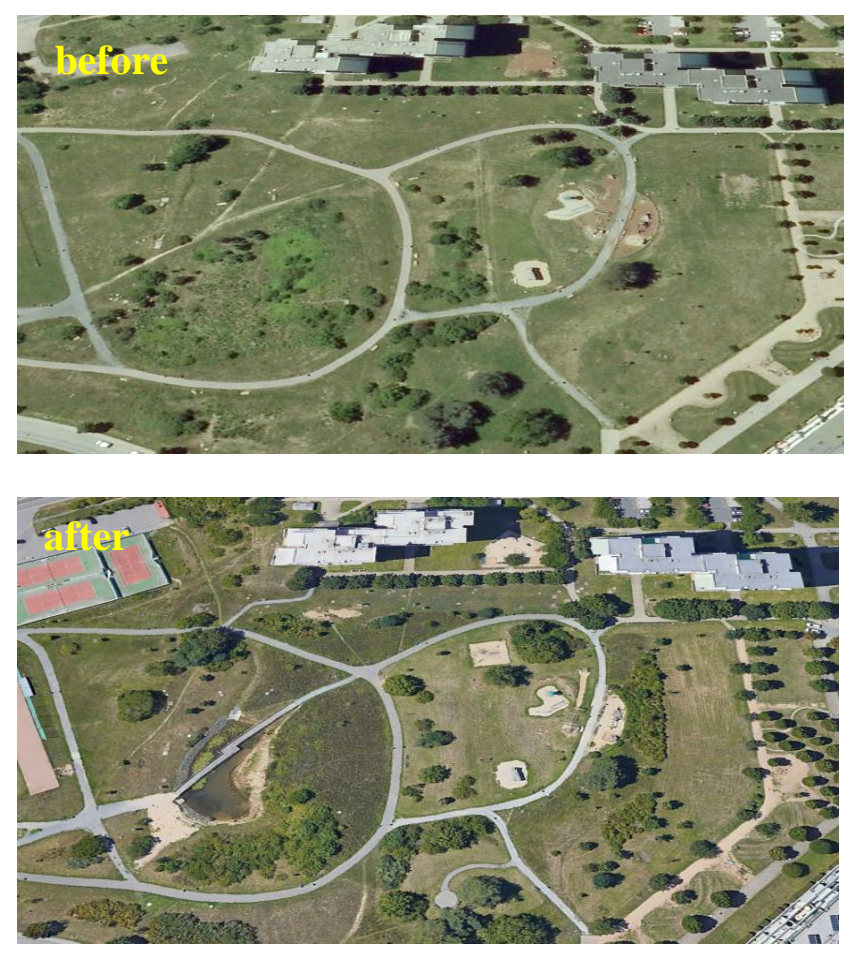

Figure 2. Comparison of the area before and after building of the retention water tank (source: Google Earth, 2020)

The tank is filled with water from precipitation collected from the roofs of two surrounding buildings by underground pipes. The total volume of this tank is up to $890 \mathrm{~m}^{3}$, while the constant water level is $630 \mathrm{~m}^{3}[19]$. The captured water is then gradually released into the storm sewer system. The constant water level is during droughts filled from the nearby drilled well.

This project of building a natural biotope inside the city brought a new natural life to the whole area (Figure 3), and in addition of its microclimatic function - cooling the surrounding environment due to evaporation, it also has a nature-friendly and educational function. The area is now considered an attractive green public space.
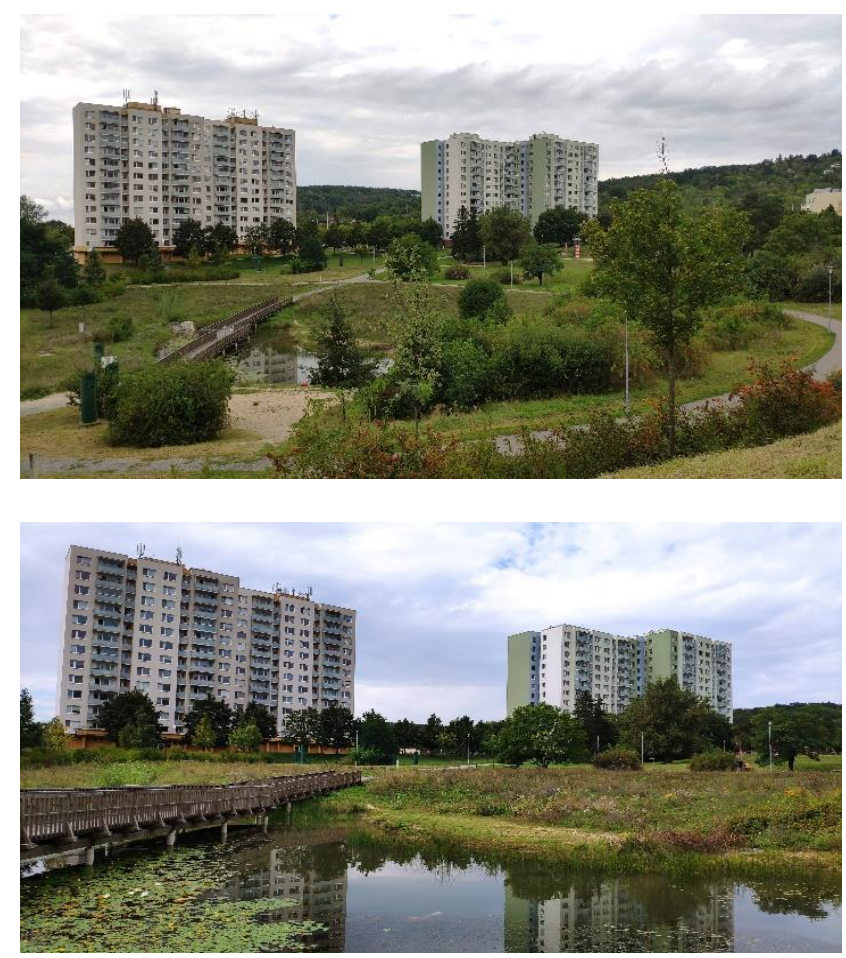

Figure 3. Above-ground retention tank in Brno, Czech Republic (source: Author, 2020)

\section{Green Roofs in the Open Garden}

One of the effective preventions against the emergence of urban heat islands is the expansion and revitalization of greenery, especially on roofs, facades and other technical structures. Green roofs or roofs with permanent vegetative growth are considered to be an appropriate measure to combat ongoing climate change due to its many environmental and economic benefits and functions, such as rainwater retention, urban air cooling due to evaporation, or insulation properties.

The properties of vegetative roofs often depend on the quality and composition of their substrate. New methods and innovative compositions of the roof substrate are being developed to achieve its best possible properties. 
Green roofs have to withstand various environmental challenges, the most common dry seasons, low nutrient content, small substrate thickness or high summer temperatures affecting the life of the roof's vegetation component. They offer many benefits and contribute to the ecological quality of the environment and building as well [20].

The case study shows an open community garden, which includes two built administrative passive buildings, built in 2013 on the site of a dilapidated building, as shown in Figure 4. The area is focused on nature friendly rainwater management and innovative technologies that help save energy with a photovoltaic power plant, thus significantly saving funds for its operation. This project also considered the treatment of gray water, which does not flow into the sewer, but is cleaned in a root zone wastewater treatment plant directly in the area.
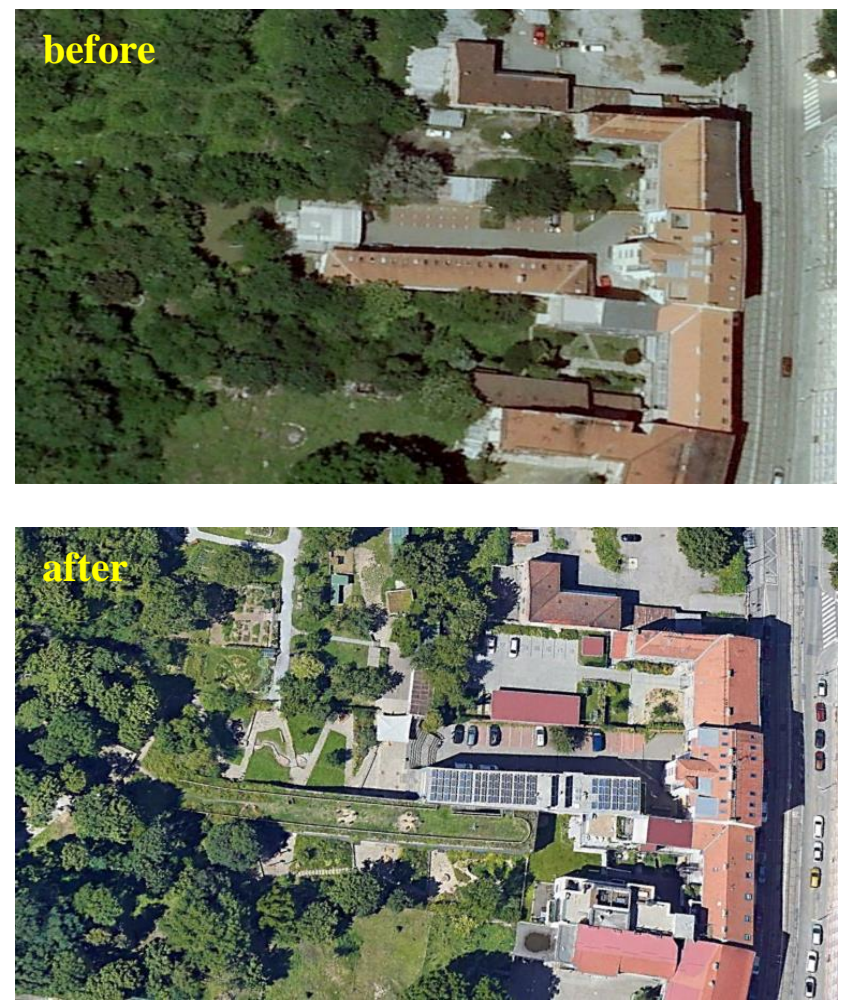

Figure 4. Comparison of the area before and after construction of the community garden and the passive building with green roof (source: Google Earth, 2020)

There are three green roofs in the area, on which measurements of the balance of rainfall runoff are performed. Two extensive, lighter roofs are fitted to the local buffet and garden kitchen. The composition of the roofs is designed to minimize the load on the roof structures of these buildings. A special mat made of recycled materials is placed on the drainage layer and hydrophilic wool. The top layer of the roof is covered with a pre-grown stonecrop carpet.

The green intensive roof on the passive buildings shown in Figure 5 helps retain the rainwater thanks to the substrate of $200-350 \mathrm{~mm}$ thick. The roof vegetation consists of different types of grasses, perennials and some types of herbs [21].

The rainwater retained by the built green roofs has the possibility of evaporation, which contributes to the cooling of the city, especially during the summer months. Temperature maps from the green roof area confirm that its surface temperature is close to the surrounding grassland and trees around $20-30{ }^{\circ} \mathrm{C}$, while standard roofs show a temperature variance of up to $60-70{ }^{\circ} \mathrm{C}$.

The built intensive green roof contributes to the comfort of the indoor environment and to energy savings for its heating or cooling. Equally significant is the impact of green roofs on the energy balance. The vegetation of the vegetation can consume up to $69 \%$ of the incident energy from the sun, which would heat the city in case of using ordinary gray infrastructure. Thus, the cooling effect that green roofs clearly provide contributes to the improvement of the urban microclimate.
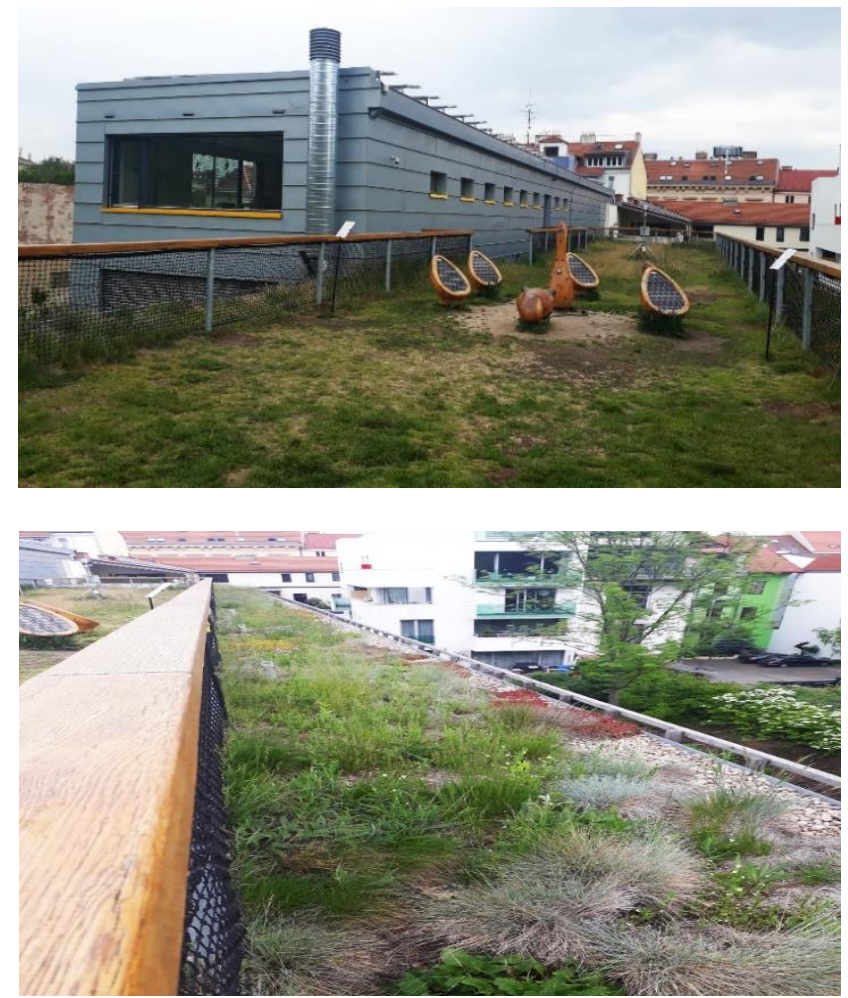

Figure 5. Green intensive roof at the passive building (source: Author, 2019)

\section{Grass Covered Tram Tracks}

Tramway lines are one of the traffic areas in cities that has the potential to positively affect the urban environment. These traffic tracks usually belong to the gray infrastructure and often form a significant area within the urban space. Their reconstruction to the so-called green tramway lines overgrown with vegetation can contribute to improving the quality of urban life and its microclimate. 
The grass covered types of tracks are gradually being built in cities not only in Europe but also around the world, as they bring a range of benefits, from noise and dust reduction to rainwater harvesting, which are the most pressing environmental problems in today's urban environment.

The case study below shows the reconstruction of tram tracks where the existing concrete panels has been replaced by the installation of a green lawn strip as shown in Figure 6. The reconstruction was completed in August 2020.
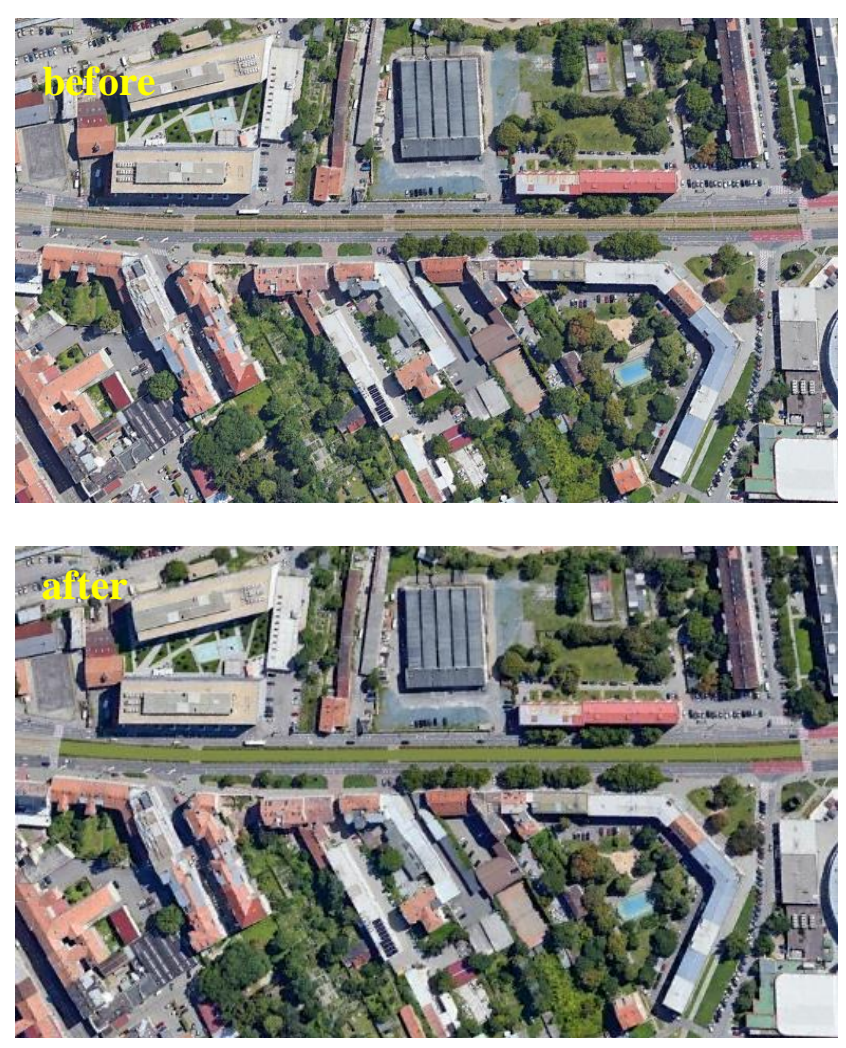

Figure 6. Comparison of the area before and after construction of the green tramway lane (source: Google Earth, 2020)

The result of the track reconstruction project is, in addition to the repaired tracks, also the installation of a green grass strip on a section approximately 430 meters long. The "Nové sady" street, where the track was reconstructed, gained a new, more natural atmosphere, which, in addition to its aesthetic function has to also fulfill its ecological and waterretaining function (see Figure 7).

The combination of rubber sidewalls on rails and lawns leads to the reduction of traffic noise. Green belts will also help reduce dust in this traffic busy area. In the past, a continuous strip of shrubs ran along the tram line, replacing with strip of greenery including a lawn with meadow flowers. The grass track is equipped with an automatic irrigation system which, in addition to maintaining the lawn, will also help to increase the humidity of the microclimate in this area.
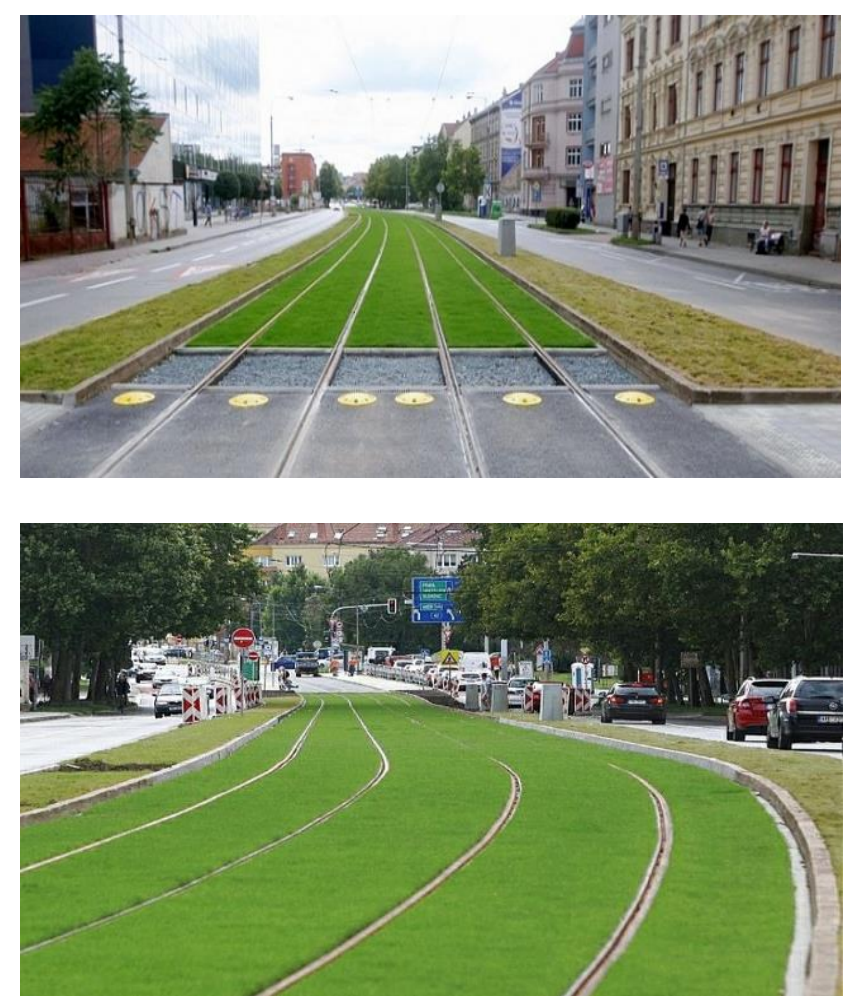

Figure 7. Green tramway lane (source: Author, 2020)

\section{Environmental and Economic Evaluation of the Built Measures}

All methods named above are considered to be the ecological approach to sustainable water management and urban development.

The following benefits follow the listed GI applications:

- water retention in the area promotes a small water cycle and cools down urban climate;

- restoration and creation of new biotopes;

- the possibility of rainwater reuse;

- protection of rare ground and above-ground water sources in the country;

- noise and dust reduction;

- air quality improvement;

- increase of the aesthetic value of the area;

- savings on bills for water and drainage of rainwater into the sewer.

Figure 8 shows the analysis of the selected benefits of each application. All the applications are most beneficial for rainwater retention and microclimate regulation function due to the vegetative water capturing areas and the possibility of its further evaporation. Retention tank and green roof are more aesthetical due to the wider possibility in the diversity of vegetation planting and they also provide a recreational function for the inhabitants, however, they offer less quality in noise reduction opposite to green tram tracks. Despite some reduced benefits, all the measures help cities to become more resilient and are effective in adaptation the urban areas to occurring climate change. 


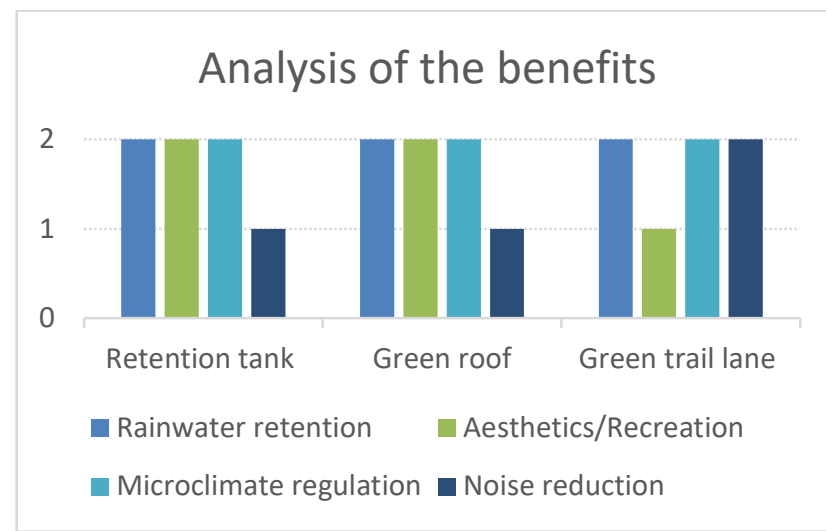

Figure 8. Analysis of the selected environmental benefits of built measures

A summary of the final costs of all three mentioned case studies with estimated years of the payback is shown in Table 2 .

The total investments in the project Park pod Plachtami amounted to 10274915 CZK. The cost of the park without a retention tank and the drainage of water from the surrounding roofs (i.e. green areas) amounted to 4.1 million CZK. The rest was the cost of the tank itself. The operating cost amount is about 300000 CZK per year. Over the years, it will be necessary to gradually repair or change some elements [19]. Larger investments in renewal are expected every 15 years (play elements, gazebo, roads, replanting of greenery, etc.).

In the case of the green roof, the reconstruction of the original building, the creation of the adjacent educational garden and the construction of the passive building cost a total of 103.9 million CZK. Operating costs are mainly the mowing and watering of the intensively used part during the summer heat [21]. The reconstruction cost was about 20 percent more than originally estimated. The return on each technology used in the Open Garden area is between 7-10 years. Their expected service life is at least 20 years (photovoltaic panels). The lifespan of a passive house is according to the investors considered to be between $40-80$ years.

The result of the grass covered tram track reconstruction, where the cost of the whole construction amounted to almost 46 million CZK includes also the reconstruction of two tram stops. The cost also includes side panels, fastener covers, and vegetation in the rail area and on the sides, lawn irrigation as well as its independent maintenance [22].In addition, the combination of rubber side panels on rails and lawns reduces traffic noise as well as dust. The estimated return of the investment of tram track reconstruction will be in 5-7 years.
Table 2. Evaluation of total investments and estimation of payback period of the built measures

\begin{tabular}{|c|c|c|}
\hline & $\begin{array}{c}\text { Total investments } \\
\text { without taxes } \\
\text { (CZK / app. } €)\end{array}$ & $\begin{array}{c}\text { Estimated } \\
\text { payback } \\
\text { period (years) }\end{array}$ \\
\hline $\begin{array}{c}\text { Retention } \\
\text { tank }\end{array}$ & $5041322 / 184960$ & 3 \\
\hline $\begin{array}{c}\text { Green roof } \\
\text { Green trail } \\
\text { lane }\end{array}$ & $103900000 / 3812040$ & $7-10$ \\
\hline
\end{tabular}

\section{Conclusion}

The idea of incorporating the concept of GI and sustainable water management into the urban planning is an excellent opportunity to design urban areas that respond to future needs. These concepts are based on the ecosystem approach, contributing to the health, resilience and prosperity of the cities. In the past, greenery was designed rather incoherently, and unsystematically. In the future the concept of GI should be considered the beginning of any urban project or strategy. Whether it is improving the quality of existing urban green areas or creating new ones, multifunctionality and connectivity are always crucial.

In order to achieve the objectives expected from the application of GI its and appropriate measures in the context of the adaptation of cities to climate change, it is necessary to use the principles, processes and forms of intervention in terms of flexibility and adaptability of spatial planning. This discipline can ensure a more sustainable balance between the requirements of urban $\mathrm{SD}$, water management and ecosystem services through deliberate and adaptive processes. The holistic approach and the well-planned implementation of adaptation measures, whether in the field of water management or spatial planning, can help create more viable cities that are resilient to climate change. The integration of innovative methods in conjunction with interdisciplinary approaches can positively affect the microclimate and temperature in urbanizations, support the small urban water cycle and help combat the effects and consequences of climate change.

\section{Acknowledgements}

This article was created as part of application of project VEGA No 1/0511/19 and VEGA 1/0382/19. 


\section{References}

[1]. Beaulieu, L., van Durne, G., Arpin, M. (2016). Circular Economy: A Critical Literature Review of Concepts. CIRAIG. Canadian Electronic Library, Montréal, Québec, Ottawa, Ontario. ISBN 978-2-9815420-0-7.

[2]. WCED. (1987). Our Common Future (Brundtland Report). Oxford, New York: United Nations through the Oxford University Press. ISBN 019282080X 9780192820808.

[3]. Tokarcíková, E., Kucharcíková, A., \& `Durišová, M. (2017). Corporate social responsibility managers and their decision making. Turk. Online J. Educ. Technol, 654-664.

[4]. Su, B., Heshmati, A., Geng, Y., \& Yu, X. (2013). A review of the circular economy in China: moving from rhetoric to implementation. Journal of cleaner production, 42, 215-227.

DOI:10.1016/j.jclepro.2012.11.020

[5]. Preston, F. (2012). A global redesign? Shaping the circular economy. Retrieved from:

https://www.biblioteca.fundacionicbc.edu.ar/images/d /d7/Bp0312_preston.pdf

[accessed: 20 September 2020].

[6]. MacArthur, E. (2013). Towards the Circular Economy: Economic and Business Rationale for an Accelerated Transition-executive Summary.

Retrieved from:

http://www.ellenmacarthurfoundation.org/business/re ports/ce2012. [accessed: 25 September 2020].

[7]. Nguyen, H., Stuchtey, M., \& Zils, M. (2014). Remaking the industrial economy.McKinsey Quarterly, 1, 46-63. Retrieved from:

https://www.mckinsey.com/business-

functions/sustainability/our-insights/remaking-theindustrial-economy. [accessed: 25 September 2020].

[8]. European Commission. (2015, December 2). Communication From The Commission To The European Parliament, The Council, The European Economic And Social Committee And The Committee Of The Regions Closing the loop - An EU action plan for the Circular Economy. COM/2015/0614 final, Brussels, 2.12.2015.

[9]. Gasparík, J., \& Szalayová, S. (2015). Optimal method of building elevator selection from the point of their energy consumption minimizing. In ISARC. Proceedings of the International Symposium on Automation and Robotics in Construction (Vol. 32, p. 1). IAARC Publications. DOI: 10.22260/ISARC2015/0120

[10]. Sgroi, M., Vagliasindi, F. G., \& Roccaro, P. (2018). Feasibility, sustainability and circular economy concepts in water reuse. Current opinion in environmental Science \& Health, 2, 20-25.

DOI:10.1016/j.coesh.2018.01.004 .

[11]. Maggo, D., \& Patil, S. (2017, Jun 7). Leading companies launch "Business Guide to Circular Water Management". Retrieved from:

https://www.wbcsd.org/Programs/Food-and-

Nature/Water/News/Business-Guide-to-Circular-

Water-Management. [accessed: 28 September 2020].
[12]. Ďurišová, M. (2011). Application of cost models in transportation companies. Periodica Polytechnica Social and Management Sciences, 19(1), 19-24.

DOI:10.3311/pp.so.2011-1.03 .

[13]. Tokarčíková, E., Malichova, E., Kucharčíková, A., \& Durišová, M. (2020). Importance of Technical and Business Skills for Future IT Professionals. Amfiteatru Economic, 22(54), 567-578. DOI:10.24818/EA/2020/54/567 .

[14]. Voulvoulis, N. (2018). Water reuse from a circular economy perspective and potential risks from an unregulated approach. Current Opinion in Environmental Science \& Health, 2, 32-45. DOI:10.1016/j.coesh.2018.01.005 .

[15]. Agócsová, Á., \& Högyeová, M. (2020). Adapting cities for climate change using the principles of urban and landscape planning. Urban Waters 2020. Brno: ARDEC, 2020, p. 183-190. ISBN 978-80-86020-91-4.

[16]. Slätmo, E., Nilsson, K., \& Turunen, E. (2019). Implementing green infrastructure in spatial planning in Europe. Land, 8(4), 62. DOI: 10.3390/land8040062

[17]. Marot, N., Golobič, M., \& Müller, B. (2015). Green infrastructure in Central, Eastern and South Eastern Europe: A universal solution to current environmental and spatial challenges?. Urbani Izziv, 26, S1-S12. DOI:10.5379/urbani-izziv-en-2015-26-supplement000 .

[18]. Tokarčiková, E. (2011). Influence of social networking for enterprise' s activities. Periodica polytechnica social and Management Sciences, 19(1), 37-41. DOI:10.3311/pp.so.2011- 1.05

[19]. Macháč, J., Dubová, L., Louda, J., et al. (2019). Methodology for Economic Assessment of Green and Blue Infrastructure in Human Settlements. Institute for Economic and Environmental Policy. Faculty of Social and Economic Studies, Jan Evangelista Purkyně University in Ústí nad Labem, Czech Republic, August 2019, First edition, 61 pages. DOI:10.13140/RG.2.2.18253.38880

[20]. Gašparík, J., Szalayová, S., Alamro, B., \& Gašparík, M. (2019, March). Optimization method of elevator selection for the realization of construction processes. In Advances and Trends in Engineering Sciences and Technologies III: Proceedings of the 3rd International Conference on Engineering Sciences and Technologies (ESaT 2018), September 12-14, 2018, High Tatras Mountains, Tatranské Matliare, Slovak Republic (p. 369). CRC Press. DOI: $10.1201 / 9780429021596-58$

[21]. Čech, M. (2019). Open Garden Areal in Brno. Nadace Partnerství. Adapterra Awards.

Retrieved from: https://www.adapterraawards.cz/Databaze/2019/Areal -Otevrena-zahrada-v-Brne [accessed: 03 November 2020].

[22]. DPMB. (2020). Opravy a stavby DPMB v průběhu letních prázdnin. Repairs and construction of DPMB during the summer holidays. Retrieved from: https://dpmb.cz/cs/download/6512 [accessed: 03 November 2020]. 